\title{
Scanning Electron Microscopy of Epididymal Ducts in the Japanese Monkey (Macacus fuscatus) with Special Reference to the Architectural Analysis of Stereocilia
}

\author{
Masahiro Murakami, Tatsuo Shimada, Chien-Tuan Huang, \\ and Ikuo ÖBAYASH
}

Received March 10, 1975

Summary. The luminal surface of the initial segment of the epididymal duct in the Japanese monkey was observed under a field emission type scanning electron microscope.

The long, slender stereocilia projecting from the apical surface of the columnar cells were found to be closely arranged in a funnel-like form opening to the lumen. The funnels formed by stereocilia were also confirmed by observation of thin sections cut from the same specimen used for scanning electron microscopy and their bottom was located in the center of the vertex of each columnar cell.

The fine structures of the mammalian epididymal epithelium under normal and experimental conditions have been described in recent years by a number of investigators using transmission electron microscopy (HonjIn et al., $1960 \mathrm{a}, \mathrm{b}, \mathrm{c}$; HorstmanN 1961, 1962, 1964; Burgos, 1964; Leeson and Leeson, 1964; Nicander, 1965; Flickinger, 1972, Nicander and Glover, 1973; Hoffer et al., 1973, a, b; Orgebin and Davies, 1974) and it was demonstrated that the tall columnar cells lining the epididymal lumen show ultrastructural properties distinctly different from absorbing cells like those of the intestine and renal tubules, and that their stereocilia are composed of complexes of delicate microvilli with a fibrillar internal structure. However, little attention seems to have been paid so far to the three-dimensional analysis of stereocilia.

On the other hand, there is no information in literature concerning the surface fine structure of the epididymal duct as observed by scanning electron microscopy, except for the brief report by MARINOzzI (1971) on that in rats, which was not satisfactory for understanding the surface details of the epididymal epithelium including stereocilia.

The present investigation deals with scanning electron microscopic analysis of the epithelial surface of the epididymal duct in the Japanese monkey with specific references to the stereocilia. The observations are confined to the initial segment of the duct.

\section{Materials and Methods}

Two adult Japanese monkeys (Macaca fuscata) weighing 10-12kg were used. Under nembutal anesthesia the animals were killed by perfusion through the ascending aorta with a mixture of $2 \%$ formaldehyde and $2.5 \%$ glutaraldehyde added with $0.025 \% \mathrm{CaCl}_{2}$ in cacodylate buffer at $\mathrm{pH}$ 7.2. Following perfusion the initial segment was bilaterally dissected free from the rest of the epididymis and left in the same 
mixture for at least 2 days at $4^{\circ} \mathrm{C}$. The specimens were cut into small pieces on a Sorvall tissue sectioner and washed gently several times in physiological saline, postfixed in buffered $2 \%$ osmium tetroxide, dehydrated through ascending concentrations of acetone, passed to amylacetate and dried with liquid carbon dioxide in a Hitachi critical point dryer CHP-1 type. After critical point drying the specimens were coated with gold in a vacuum using a Geiko ion cleaner LBD type equipped with spattering adapter and viewed in a Hitachi field emission scanning electron microscope HFS-2 type.

For the purpose of identifying the structure responsible for surface contour some of the specimens were placed in propylene oxide and embedded in Epon 812 following scanning electron microscopy. Thin sections were prepared in the usual manner for transmission electron microscopy.

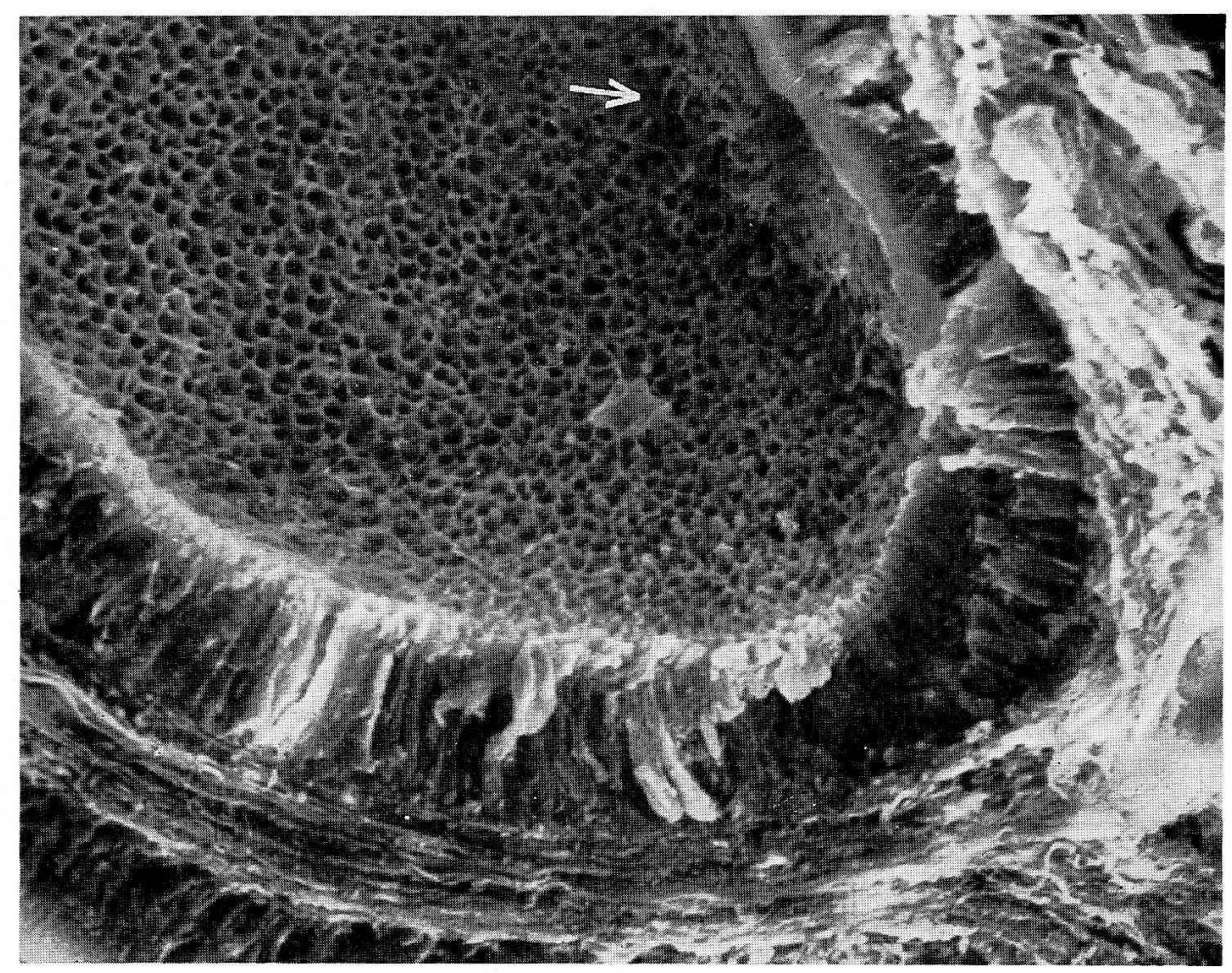

Fig. 1. Survey scanning electron micrograph of the initial segment of an epididymal duct. The luminal surface lined by the tall pseudostratified columnar epithelium gives an appearance of a honeycomb. Moderate numbers of spermatozoa are also visible in the lumen near the apical surface of the columnar cells (arrow) $\times 330$

Fig. 2. Mid-range-magnification scanning electron micrograph of the luminal surface of an epididymal duct. The stereocilia are arranged in a funnel-like form opening upwards. $\times 2,400$

Fig. 3. High magnification electron micrograph showing individual stereocilia composing the funnel wall. $\times 60,000$ 

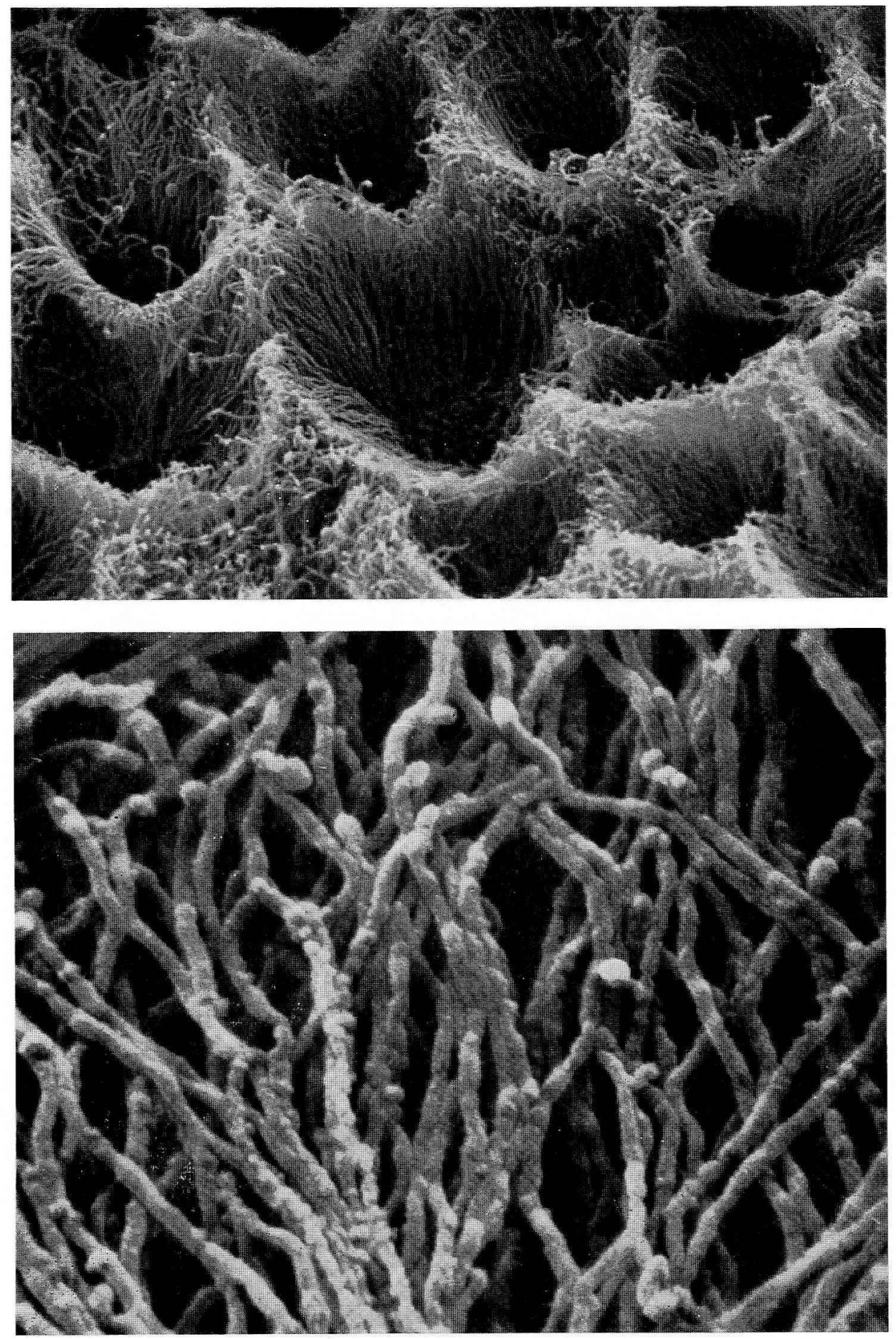


\section{Results}

Survey scanning electron microscopy reveals that the epididymal lumen is lined by tall columnar cells which are about $50 \mu$ in height and surrounded completely by several layers of smooth muscle cells arranged in parallel as already known by previous light and transmission electron microscopy. The luminal surface of the epididymal duct gives the appearance of a honeycomb due to the peculiar arrangement of stereocilia projecting from the columnar cells (Fig. 1).

The stereocilia are not uniform in length and distribution as in the case of microvilli of the intestinal absorbtive cells, but leave a funnel-shaped space widely opening to the lumen on the center of each cell. The surface of the funnel is usually masked all over by a gelatinous substance in which individual stereocilia are embedded adhering tightly to each other. In the specimen washed vigorously with a physiological saline, however, the delicate network of stereocilia composing the frame of the funnel is exposed (Fig. 2). The funnel is probably formed by the central stereocilia which are conspicuously short and by the peripheral longer ones which run a divergent course towards the lumen. Individual stereocilia are in general long and slender, they vary in length from 2 to $8 \mu$, but are almost constant in diameter $(120 \mathrm{~m} \mu)$

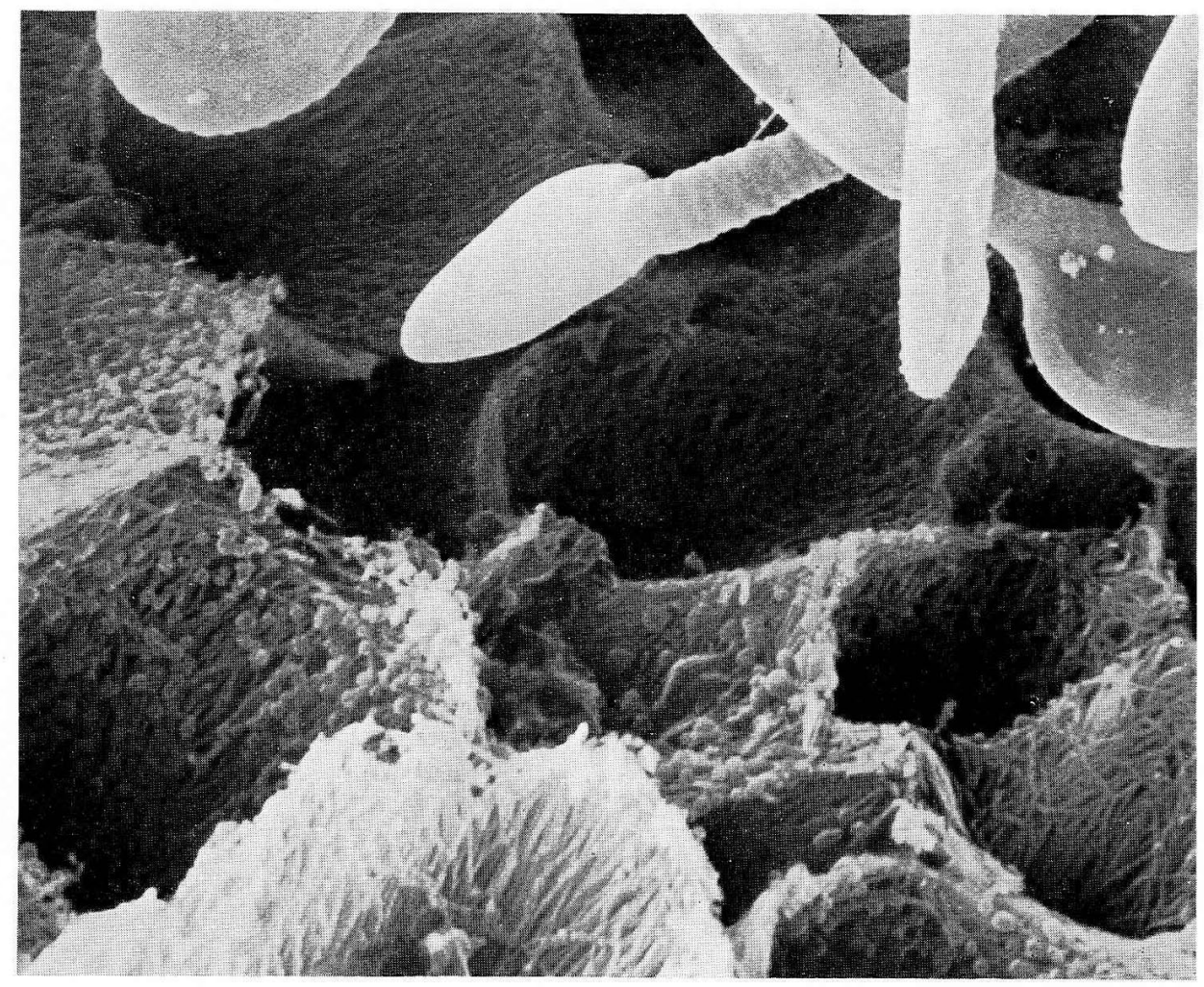

Fig. 4. Mid-range-magnification scanning electron micrograph showing spermatozoa floating in the lumen of an epididymal duct. $\times 11,000$ 


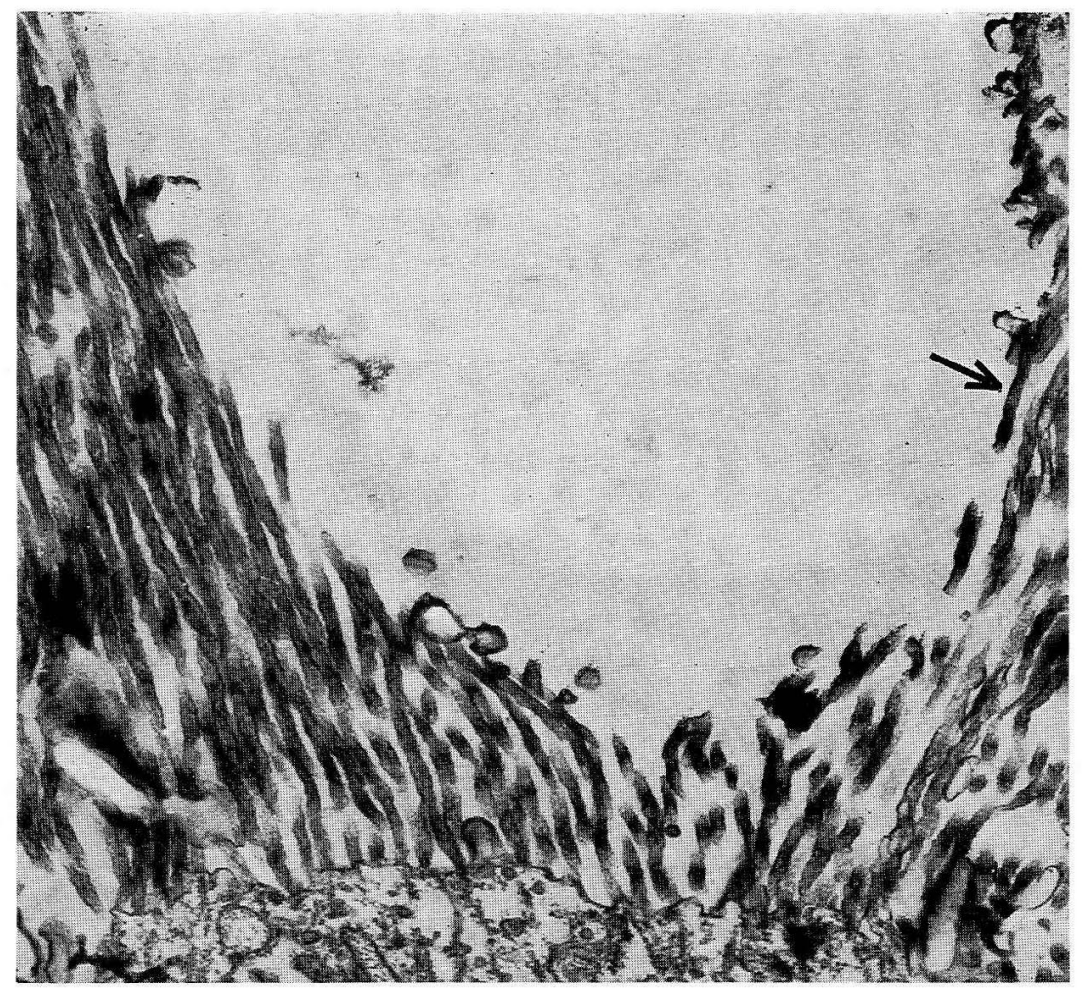

Fig. 5. Transmission electron micrograph of the apical part of an epididymal columnar cell in longitudinal section near the center of the cell. Thin gold coat is observed partially covering the exposed surface of stereocilia (arrow). $\quad \times 22,400$

from the base to the tip. Their outer surface seems smooth and without a particular structure. Frequently small globules are found to adhere to the tip or the shaft of the stereocilia; they may be artifacts produced during preparation (Fig. 3). Bifurcated stereocilia are not detected with certainty in the present study. Variable numbers of spermatozoa are always present floating in the lumen over the stereocilia as shown in Figure 4. They are never found to invade deep into the cavity of the funnel.

In thin sections cut from the same specimens embedded in plastic following scanning electron microscopy, the fine structure of the epididymal epithelium is well preserved and can be correlated closely with the findings obtained by scanning electron microscopy. The stereocilia are longer towards the periphery of each columnar cell and tend to diverge to form a cone opening to the lumen. The thin section also confirms that the center of the apical surface of the columnar cells corresponds to the bottom of the funnel (Fig. 5).

\section{Discussion}

It has already been shown by previous light microscopy that the stereocilia lining the luminal surface of the epididymal epithelium are found to be matted together to form a tuft and the recent transmission electron microscopy demonstrates that they 
are projected radially towards the lumen from the apical cell surface (HoRstmanN, 1961) or bent in the direction of the intraluminar current (NICANDER, 1965). However, it has been difficult to visualize the three dimensional distribution of the stereocilia by the routine techniques of light- and transmission electron microscopy.

To our knowlege, the only illustration in literature as to the stereogram of the epididymal stereocilia is the textbook of histology by ELIAS and PAULY (1966), in which the stereocilia with a regular bifurcation were arranged sparsely along the boundaries of each columnar cell, while the remaining part of the cell vertex was completely lacking in stereocilia.

The present scanning electron microscopy of the epididymal duct in the Japanese monkey clearly revealed that the stereocilia rise thickly from the apical surface of the columnar cell and diverge in a funnel-like form. Furthermore, the thin section cut from the same specimen used for scanning electron microscopy confirmed that the center of each columnar cell corresponded to the bottom of the funnel.

The question as to whether such a funnel-like arrangement of the stereocilia accurately represents the living state or is an artificial product caused during specimen preparation, especially by the critical point drying method employed may not be answered definitely. However, since the superiority of the critical point drying method in preventing much of the mechanical distortion is now widely accepted and since the thin section obtained from the same specimen following scanning electron microscopy in the present study also showed excellent preservation of the epididymal epithelium at the fine structural level, the funnel-like arrangement of the stereocilia observed is considered as an accurate representation of the state in situ rather than a preparation artifact, although the significance of this peculiar arrangement of stereocilia in the epididymal function is not clear.

\title{
ニホンザル精巣上体管の走査電子顕微鏡による観察，特に不動毛の 立体的構築について
}

\author{
村上正浩，島田達生，黄 建団，大林育生
}

成熟ニホンザル精巣上体管起始部の内腔表面を電界放射型走査電子顕微鏡で観察した.

内腔を縁どる高円柱上皮の表面には 細長い不動毛が密生しており,これら不動毛は上方 に開いた漏斗の恰好に配列している. 走査電子顕微鏡で観察した同じ試料をエポンに包埋 して得た超薄切片の透過電子顕微鏡像では，漏斗の底部は高円柱上皮表面の中央に相当す る.

\section{References}

Burgos, M. M. : Uptake of colloidal particles by cells of the caput epididymis. Anat. Rec. 148: 517-525 (1964).

Elias, H. and J. E. Pauly : Human microanatomy. Edition 3, Philadelphia, F. A. Davis Co., 1966. 
Flickinger, C. J.: Alterations in the fine structure of the rat epididymis. Anat. Rec. 173: 277300 (1972).

Hoffer, A. P., D. W. Hamilton and D. W. Fawcett : The ultrastructure of the principal cells and interepithelial leucocytes in the initial segment of the rat epididymis. Anat. Rec. 175: 169-202 (1973a).

stration of $\alpha$-chlorhydrin U-5897. Anat. Rec. 175: 203-230 (1973b).

Honjin, R., Y. Hirai, T. Nakamura and T. Okumura: Electron microscopic studies on the epithelial cells of the epididymis, with special reference to the morphological changes of intracellular ultrastructures induced by experimental section of the pelvic nerve and castration. Report 1. On the ultrastructures of the epithelial cells of epididymis of the normal mouse (Jap. with Engl. abstr.). Juzenkaishi 64: 257-259 (1960a).

Honjin, R., T. Uozu and A. Nakanishi : Electron microscopic studies on the epithelial cells of the epididymis, with special reference to the morphological changes of intracellular ultrastructures induced by experimental section of the pelvic nerve and castration. Report 2. On the effects of experimental section of the pelvic nerve on the intracellular ultrastructures. Report 3. On the effects of castration on intracellular ultrastructure. (Jap. with Engl. abstr.) Juzenkaishi 64: 270-280, 281-288 (1960b,c).

Horstmann, E. : Die Struktur der Stereocilien des Nebenhodenepithels. Deutsch. med. Wochenschr. 86: 2484 (1961).

-: Elektronenmikroskopie des menschlichen Nebenhodenepithels. Z. Zellforsch. 57: 692718 (1962).

- : Elektronenmikroskopische Beobachtungen über die Struktur und Variabilität der Stereocilien im Ductus epididymidis des Menschen. Verh. Anat. Ges. 58: 224-230 (1964).

Leeson C. R. and T. S. Leeson: An electron microscope study of the postnatal development of the ductus epididymis in the rat. Anat. Anz. 114: 168-180 (1964).

Marinozzi, G.: Primi rilievi al microscopic electronico a scansione su alcuni tratti dell'epididimo e del testicolo nel topo. Boll. Soc. Ital. Biol. Sperimentale. 47: 552-553 (1971).

Nicander, L.: An electron microscopic study of absorbing cells in the posterior caput epididymis of rabbits. Z. Zellforsch. 66: 829-847 (1965).

Nicander, L. and T. D. Glover: Regional histology and fine structure of the epididymal duct in the golden hamster (Gallus domesticus). J. Anat. 114: 347-365 (1973).

Orgebin-Crist, M. C. and J. Davies: Functional and morphological effects of hypophysectomy and androgen replacement in the rabbit epididymis. Cell Tiss. Res. 148: 183-202 (1974).

村上正浩

厂 830 久留米市旭町 67

久留米大学医学部

解剖学教室
Dr. Masahiro Murakami

Department of Anatomy

Krume University School of Medicine

Kurume, 830 Japan 